Article

\title{
Antimicrobial Activity of Chrysoeriol 7 and Chochlioquinone 9, White-Backed Planthopper-Resistant Compounds, Against Rice Pathogenic Strains
}

\author{
Yoon-Hee Jang, Jae-Ryoung Park and Kyung-Min Kim * \\ Division of Plant Biosciences, School of Applied Biosciences, College of Agriculture and Life Science, \\ Kyungpook National University, Daegu 41566, Korea; uniunnie@naver.com (Y.-H.J.); icd92@naver.com (J.-R.P.) \\ * Correspondence: kkm@knu.ac.kr; Tel.: +82-539-505-711; Fax: +82-539-586-880
}

Received: 23 September 2020; Accepted: 5 November 2020; Published: 7 November 2020

Simple Summary: This study is an important contribution to the development of biopesticide materials for controlling major pathogens in rice. Chrysoeriol 7 and cochlioquinone 9, which repel the white-backed planthopper, were extracted from rice and their antimicrobial activity was investigated. The results show they are effective in limiting the growth of pathogens of the genera Fusarium, Cladosporium and Pythium. This shows that they have great potential as an alternative to chemical pesticides and is also thought to be helpful in development of eco-friendly agriculture.

\begin{abstract}
As environmental damage caused by chemical pesticides appears worldwide, eco-friendly agriculture is increasing, and finding eco-friendly pesticide materials has become very important. Chrysoeriol and cochlioquinone, two flavonoids, act as an antibacterial and antioxidant, and increase the resistance of rice to the white-backed planthopper (WBPH). In this experiment, chrysoeriol 7 (C7) and cochlioquinone 9 (C9) were extracted from rice inoculated with the WBPH using $\mathrm{MeOH}$, and cultivars with high extraction efficiency were selected. In addition, the antimicrobial activity of $C 7$ and $C 9$ against various pathogens causing disease in rice was tested. The results show that C7 has antifungal activity against Fusarium graminearum and Pythium graminicola, and C9 show antifungal activity against Cladosporium herbarum, Cladosporium cladosporioides, Gibberella zeae, Fusarium graminearum and Pythium graminicola. When both substances were treated at a concentration of $1000 \mathrm{ppm}$, they showed high inhibition rates of $62.3 \%$ and $36.2 \%$ against P. graminicola, respectively. After that, a phylogenetic tree was created to clarify the relationship between the microorganisms whose growth was inhibited and divided into three groups. This result can contribute to the study of biopesticide materials that can control pests and pathogens.
\end{abstract}

Keywords: rice; antimicrobial; white-backed planthopper; phylogenetic tree; biopesticide

\section{Introduction}

Rice (Oryza sativa L.) is the main food crop for more than $50 \%$ of the world's population, making it one of the most important crops in the world. The largest yield of rice is obtained from Asia, where about $94 \%$ of the world's supply is grown [1]. In a report on agricultural prospects by the OECD, FAO and other international organizations, the world's population will reach about 9.6 billion by 2050 and demand for food will increase by more than $60 \%$ [2]. To meet the needs of the rapidly growing population, a significant increase in rice production is needed in the coming decades.

In natural environments, however, rice is easily attacked by pests, nematodes and pathogens such as viruses, bacteria and fungi [3]. These attacks cause rice diseases and result in significant yield 
losses worldwide, threatening rice supplies and global food security. There are more than 50 kinds of rice diseases reported in Korea [4]. When the occurrence is severe, depending on the type of disease it may lead to a direct loss in yield and quality [5]. Migratory insects also cause major problems in Asia, especially Laodelphax striatellus Fallen (the small brown planthopper, SBPH), Nilaparvata lugens (the brown planthopper, BPH) and Sogatella furcifera Horvath (the white-backed planthopper, WBPH), which are well known for causing serious damage in south and east Asia [6].

Since the high-yield rice variety began to replace existing Japonica-type varieties in the Green Revolution of the 1960s, the WBPH and BPH have been the major pests causing damage to rice farms in the early summer every year from the tropical climatic regions in southern China to Korea, Japan and central China [7]. Because of the damage caused by the insects, pesticides are considered an essential tool for rice production, and are indispensable for achieving agricultural productivity [8]. Nowadays, agriculture is dependent on chemical fertilizers and organic synthetic pesticides, and problems with those substances have begun to emerge around the world [9]. To avoid those problems, environmentally friendly agriculture has become an alternative. As eco-friendly cultivation areas increase, research has been actively conducted to find eco-friendly materials with pesticidal effects that do not significantly harm the environment [10].

Some plant extract compounds contain bioactive substances and show little harm to humans, so they are recognized as pesticide substitutes in environmentally friendly agriculture $[11,12]$. Chrysoeriol, also known as 3'-O-methylluteolin, is a 3'-O-methylated flavonoid [13]. This flavonoid has a methyl group attached to the 3 atom of the flavonoid backbone. Therefore, it is considered a flavonoid lipid molecule and is a yellow needle-shaped crystal with a melting point of $337^{\circ} \mathrm{C}$ [14]. Chrysoeriol is found mostly in the leaves of Eriodictyon glutinosum Bentham and is also present in a wide variety of plants, vegetables [15], fruits [16] and flowers [17]. Chrysoeriol is of great interest scientifically because of its antioxidant, anti-inflammatory, antibacterial and antiviral properties. Glucoside bound to chrysoeriol is an isoflavonoid that plays an important defense against invasion of pathogens and insects [18]. Chrysoeriol has antimicrobial activity against various pathogens; particularly, it has been found to contain artemisinin derivatives, which are malaria drugs caused by Plasmodium falciparum [19]. Chrysoeriol glycoside isolated from G. glandulosum has antibacterial activity that destroys the cytoplasmic membrane by cell lysis and cytoplasmic permeability to leak the cellular components, killing the cells [20]. Chrysoeriol strongly induces the expression of heme oxygenase (HO)-1, an antioxidant enzyme, and at the same time promotes the intranuclear migration of the transcription factor Nrf2, thereby enhancing the antioxidant effect [21]. It also strongly inhibits the induction of nitric oxide synthase by blocking $A P-1$ activation [22]. The production of antimicrobial compounds is associated with fungal-mediated insects [23,24].

When insects invade leaves, the fungus grows around the wounds and they produce a variety of interesting plant toxins. The fungi produce phytotoxins causing plant stress, but sometimes at the same time they also produce substances to protect plants from insect attack. A cochlioquinone is a flavonoid and an antibacterial compound of the fungus vectorized by Clusia spp. The WBPH induces fungi into leaves, which then produce cochlioquinone A [25]. The parasitic fungus Cochliobolus miyabeanus produces cochlioquinone A and B, which are yellow pigments, as small metabolites [26]. Their mixed biosynthesis occurs by introducing farnesyl units into aromatic precursors where secondary methyl groups are derived from methionine [27]. Cochlioquinone is a bioactive substance and is sometimes used as a nematode agent that competes for specific $3 \mathrm{H}$ ivermectin binding sites [28]. Cochlioquinone A1 (CoA1) isolated from the fungal strain Bipolaris zeicola is used as a potent antiangiogenic agent [29]. Kim et al. (2013) [30] used the Cheongcheong/Nagdong doubled-haploid cultivar to select the WBPH-resistant strains. Park et al. (2014) [31] performed HPLC analysis of C7 (resistive compound) identified as chrysoeriol and C9 (susceptible compound) identified as cochlioquinone 9 in rice inoculated with WBPH $[30,31]$. In this study, we investigated the antimicrobial activity of chrysoeriol 7 and cochlioquinone 9 against rice pathogens by extracting and separating the WBPH-resistant material from rice, and then judge their potential as eco-friendly pesticide alternatives. 


\section{Materials and Methods}

\subsection{WBPH Breeding and Plant Material}

Fifty male and female WBPHs were obtained from the National Agricultural Science Research Institute of the Rural Development Administration (RDA). The breeding cage was made of an acrylic plate $(50 \times 50 \times 40 \mathrm{~cm})$ and a $100-\mu \mathrm{m}$ mesh net was used on the back for ventilation and water supply. The insect nursery was maintained at a temperature of $27^{\circ} \mathrm{C} \pm 1{ }^{\circ} \mathrm{C}$, a humidity of 60 to $70 \%$, a luminous intensity of 2000 lux and over a 16-h cycle. Chucheong, one of the most preferred rice cultivars for WBPHs, was used for their food. Twenty to twenty-five grams of seeds were sterilized using a Spotak pesticide, then soaked in an incubator at $33^{\circ} \mathrm{C}$ for 3 days and washed with clean water every morning. After sowing into a $21 \mathrm{~cm} \times 14 \mathrm{~cm} \times 5 \mathrm{~cm}$ plastic container and supplying sufficient moisture, the plants were placed in dark conditions at $28^{\circ} \mathrm{C}$ for 2 to 3 days, and then 2 or 3 leaf seedlings grown in a greenhouse for 1 to 2 weeks were used as feed. The food was changed every week, which helps the next generation of WBPHs to be sustained (Figure 1). When the WBPHs were at their 2 or 3 instar, they were inoculated into the plant material, namely, Cheongcheong, Nagdong and TN1.

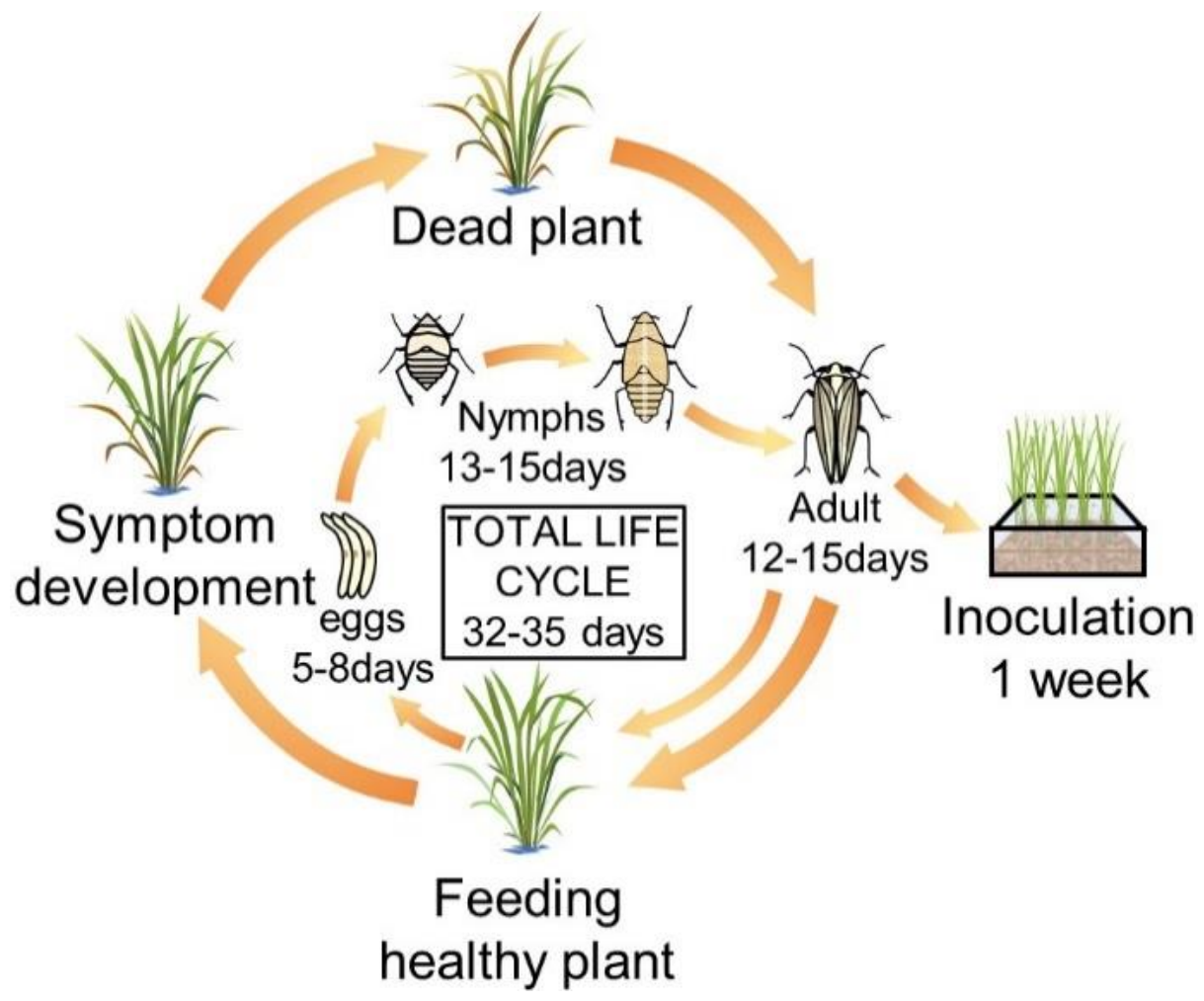

Figure 1. Breeding system and life cycle of the white-backed plant hopper (WBPH). In the breeding cage, healthy rice at the seedling stage was provided as food for the white-backed plant hoppers (WBPHs) every week. The WBPH hatches from eggs after 5-8 days and has a nymph period of 13 to 15 days. After that, it becomes an adult and is active for $12-15$ days. At this time, if new food is provided, the adult insects move to the new food. The total life cycle of the WBPH is 32 to 35 days, and the sucked rice turns yellow and dies over time.

Cheongcheong, Nagdong and TN1 were harvested at the Kyungpook National University Experimental Field at Gunwi in Korea in 2018. Cheongcheong is a resistant cultivar, and Nagdong and TN1 are cultivars sensitive toward the WBPH. Sixty grams of seeds were sterilized with $500 \mu \mathrm{L}$ of Spotak pesticide (HANKOOKSAMGONG, Seoul, South Korea) in $1 \mathrm{~L}$ of water at $33^{\circ} \mathrm{C}$ for 3 days in an incubator and washed with clean water every morning. After sowing in a plastic container $(21 \times 14 \times 5 \mathrm{~cm})$ and supplying sufficient moisture, the plants were placed in dark conditions at $28^{\circ} \mathrm{C}$ 
for 2 to 3 days and then grown in the greenhouse. The $50 \mathrm{WBPHs}$ of the 2nd or 3rd instar were inoculated into Cheongcheong, Nagdong and TN1 for a week.

\subsection{Bacterial and Fungal Pathogens}

Two bacteria and 11 fungi causing rice disease were obtained from the Agricultural and Microbiology Department of the National Academy of Agricultural Science, RDA (Table 1). The freeze-dried bacteria were suspended in $5 \mathrm{~mL}$ of Luria-Bertani (LB) broth and cultured at $30{ }^{\circ} \mathrm{C}$ and $130 \mathrm{rpm}$ for 3 days in an incubator. The freeze-dried fungi were suspended by adding $0.3-0.5 \mathrm{~mL}$ of sterile distilled water, and then the suspended samples were inoculated with $0.1 \mathrm{~mL}$ in potato dextrose agar (PDA) solid medium using a pipette and cultured at $25^{\circ} \mathrm{C}$ in an incubator for one week. After culturing, the growth and contamination of the strains were confirmed, and the purely cultured strains were used for the experiment.

Table 1. List of bacteria and fungi obtained from the Rural Development Administration (RDA).

\begin{tabular}{|c|c|c|c|c|c|}
\hline Pathogens & Scientific Name & Disease Name & KACC No. & Media & Temperature $\left({ }^{\circ} \mathrm{C}\right)$ \\
\hline Bacteria & Xanthomonas campestris pv. campestris & Bacterial Leaf Blight & 10377 & LB & 30 \\
\hline \multirow{7}{*}{ Fungi } & Alternaria tenuissima & Ear Blight & 40968 & PDA & 30 \\
\hline & Cladosporium cladosporioides & Ear Blight & 40934 & PDA & 25 \\
\hline & Alternaria padwickii & Ear Blight & 43247 & PDA & 25 \\
\hline & Gibberella zeae & Scab & 46523 & PDA & 25 \\
\hline & Fusarium graminearum & Scab & 41040 & PDA & 25 \\
\hline & Pythium graminicola & Damping-off & 40155 & PDA & 25 \\
\hline & Pythium ultimum & Damping-off & 40705 & PDA & 25 \\
\hline
\end{tabular}

\subsection{Extraction and Separation of Compounds}

The leaves of Cheongcheong, Nagdong and TN1 inoculated with the WBPHs were cut and ground using a mortar with liquid nitrogen. Thirty-five grams of each leaf was used. Then, $35.0 \mathrm{~g}$ of plant sample and $350 \mathrm{~mL}$ of $70 \%$ methanol were added in a $1000 \mathrm{~mL}$ Erlenmeyer flask and shaken overnight in an incubator at $20^{\circ} \mathrm{C}, 130 \mathrm{rpm}$. A filter paper (Whatman Grade 2 Qualitative Filter Paper Diameter: $15.0 \mathrm{~cm}$; pore size: $8 \mu \mathrm{L}$ ) was fixed in the funnel and inserted into the Erlenmeyer flask. The sample was poured onto filter paper and this filtering was repeated twice.

The sample was washed using an equal volume of n-hexane: equal amounts of sample and n-hexane were added in a separation glass, shaken for few minutes, and then left until the layers were completely separated before collecting the bottom layer of the solution. The samples were concentrated using a rotary evaporator. The concentration was carried out under conditions of a water bath temperature of $30^{\circ} \mathrm{C}$, a cooling solution at $-3{ }^{\circ} \mathrm{C}$ to $5{ }^{\circ} \mathrm{C}$ and a speed of $6-8$. The samples were concentrated until the volume was about $10 \mathrm{~mL}$ and then concentrated more using a heating block. They were heated at $60^{\circ} \mathrm{C}$ until the sample in each tube was about $0.3 \mathrm{~mL}$.

One hundred and twenty-five grams of silica gel 60 were poured into a glass column (diameter $10 \mathrm{~mm} \times 250 \mathrm{~mm}$ ) using a funnel. The silica gel was first washed with $20 \%$ methanol, and then all of the concentrated sample was added in until it was soaked in silica gel. We poured the $20 \mathrm{~mL}$ eluent into a column and waited until the solution had fallen. The eluent gradient was $4 \%$ methanol and $20 \%$ acetone. We collected the solution in the tube until all samples had come down. We dried the collecting eluent with a heating block at $50{ }^{\circ} \mathrm{C}$. After drying, the compound in some tubes was checked by TLC silica gel $60 \mathrm{~F}_{254}$ plates (Merck, KGaA, Darmstadt, Germany) with a mobile phase (Chloroform:Methanol:1-Butanol:Water = 4:5:6:4) and exposed in a UV eliminator (Bio-rad, USA).

The silica matrix containing the compound was cut to separate $C 7$ and C9. The compounds were then separated from the silica matrix using a small column and eluted by $20 \mathrm{~mL}$ of $4 \%$ methanol in 
$100 \%$ acetone to get the purified compounds. The purity of compounds was checked by TLC silica gel $60 \mathrm{~F}_{254}$ plates.

\subsection{LC/MS for Identification}

We used LC/MS to analyze the materials, with an MSQ Plus Single Quadrupole Mass Spectrometer (Thermo Fisher Scientific, San Diego, CA Waltham, MA, USA). The infusion concentration was a 1:1000 sample dilution using $50 \%$ methanol in $0.1 \%$ formic acid and the flow rate was $50 \mu \mathrm{L} / \mathrm{min}$.

\subsection{Antimicrobial Activity Test of the Compounds}

The separated compounds were dried using a heating block, dissolved with distilled water at 3 concentrations (100 parts per millions (ppm), $500 \mathrm{ppm}$ and $1000 \mathrm{ppm}$ ), and then $0.1 \mathrm{~mL}$ was applied to the medium. For the bacteria, the liquid LB medium was suspended in distilled water to have a $1.0 \mathrm{OD}$ value at $600 \mathrm{~nm}$ using a UV spectrophotometer, and then $0.1 \mathrm{~mL}$ of the bacteria was dropped into the LB medium using a pipette and cultured at $30{ }^{\circ} \mathrm{C}$ in dark conditions. For the fungi, a part of the subcultured mycelium $(0.5 \times 0.5 \mathrm{~cm})$ was transplanted to the PDA medium and cultured at $25^{\circ} \mathrm{C}$ in dark conditions. After inoculation, the growth over 1 and 2 weeks was confirmed, and the diameter of the colony was measured. According to Kim et al. (2012), the following formula (1) was used for the calculation of the inhibition rate (\%) [32].

$$
\text { Inhibition rate }(\%)=\left(1-\frac{\text { Colony diameter in treatment medium }}{\text { Colony diameter in untreated medium }}\right) \times 100
$$

\subsection{Statistical Analysis}

All experiments were replicated at least three times, and the statistical analysis was performed using the SPSS program (IMMSPSS Statistics, version 22, IBMSPSS Statistics, version 22, Redmond, WC, USA).

\subsection{Polymerase Chain Reaction Protocol and Sequencing}

Bacterial and fungal DNA were extracted from the samples using the DNeasy Plant Mini Kit (Qiagen, Hilden, Germany; Cat. No. 69104). Polymerase chain reaction (PCR) amplifications were done in $30 \mu \mathrm{L}$ mixtures containing $5 \mu \mathrm{L}$ of $20-30 \mathrm{ng} / \mathrm{mL}$ template DNA, $1 \mu \mathrm{L}$ of $10 \mathrm{pM}$ of each primer, $2 \mu \mathrm{L}$ of dNTPs, $0.3 \mu \mathrm{L}$ Ex taq polymerase (Imclone Biotech Co., Manhattan, NY, USA), $3 \mu \mathrm{L}$ of 10× Ex buffer and $12.7 \mu \mathrm{L}$ of nuclease-free water (Qiagen, Cat. No. 129114). The reaction consisted of an initial denaturation for $5 \mathrm{~min}$ at $94{ }^{\circ} \mathrm{C}$ followed by 35 cycles for $30 \mathrm{~s}$ at $94{ }^{\circ} \mathrm{C}$, annealing for $30 \mathrm{~s}$ at $55^{\circ} \mathrm{C}$ and an extension of $72{ }^{\circ} \mathrm{C}$ for $30 \mathrm{~s}$. The PCR was performed using a GeneAmp PCR System 2700 (Applied Biosystems, Waltham, MA, USA) or MyGenie96 Thermal Block (Bioneer, Daejeon, Korea). Primers were used as the universal primer 27F (5'-AGAGTTTGATCCTGGCTCAG-3'), 1492R ( $5^{\prime}$-GGTTACCTTGTTACGACTT-3'), ITS1 (5'-TCCGTAGGTGAACCTGCGG-3') and ITS4 (5'-TCCTCCGCTTATTGATATG-C-3'). Each primer targets the bacterial 16S rRNA and the fungal ITS region. After the PCR, the products were treated by electrophoresis in $1.2 \%$ agarose gel. Amplification products were purified by a QIA quick Gel Extraction Kit (Qiagen, Cat. No. 28706). Sequencing analyses were done by SolGent Co., Ltd. (Bethesda, MD, USA). The sequencing analysis for the homology search was done using the BLAST program at NCBI (http://www.ncbi.nim.nih.gov) database.

\subsection{Phylogenetic Analysis}

The sequences were aligned using Clustal W multiple alignment. Bacterial $16 \mathrm{~S}$ and fungal ITS sequences were entered in the MEGA X program (Philadelphia, PA, USA) for construction of the phylogenetic trees. The phylogenetic tree was constructed using the distance method, neighbor-joining. Branch support was given using 1000 bootstrap replicates. 


\section{Results}

\subsection{Extraction Efficiency by Variety}

After separation of C7 and C9,1.7 mg, 3.6 $\mathrm{mg}$ and $12.1 \mathrm{mg}$ of C7 and $9.0 \mathrm{mg}, 4.1 \mathrm{mg}$ and $14.0 \mathrm{mg}$ of C9 were obtained in Cheongcheong, Nagdong and TN1, respectively. The highest amount of both C7 and C9 were obtained from TN1, as confirmed by TLC.

\subsection{LC/MS Data}

LC/MS analyses were conducted to identify the compounds. The LC/MS chromatograms of C7 and C9 are shown in Figure 2. Positive and negative LC/MS data revealed the molecular weight to be 267.36 and $381.37 \mathrm{~m} / \mathrm{z}$ in C7 and 381.38 and $480.40 \mathrm{~m} / \mathrm{z}$ in C9 (Figure 2).
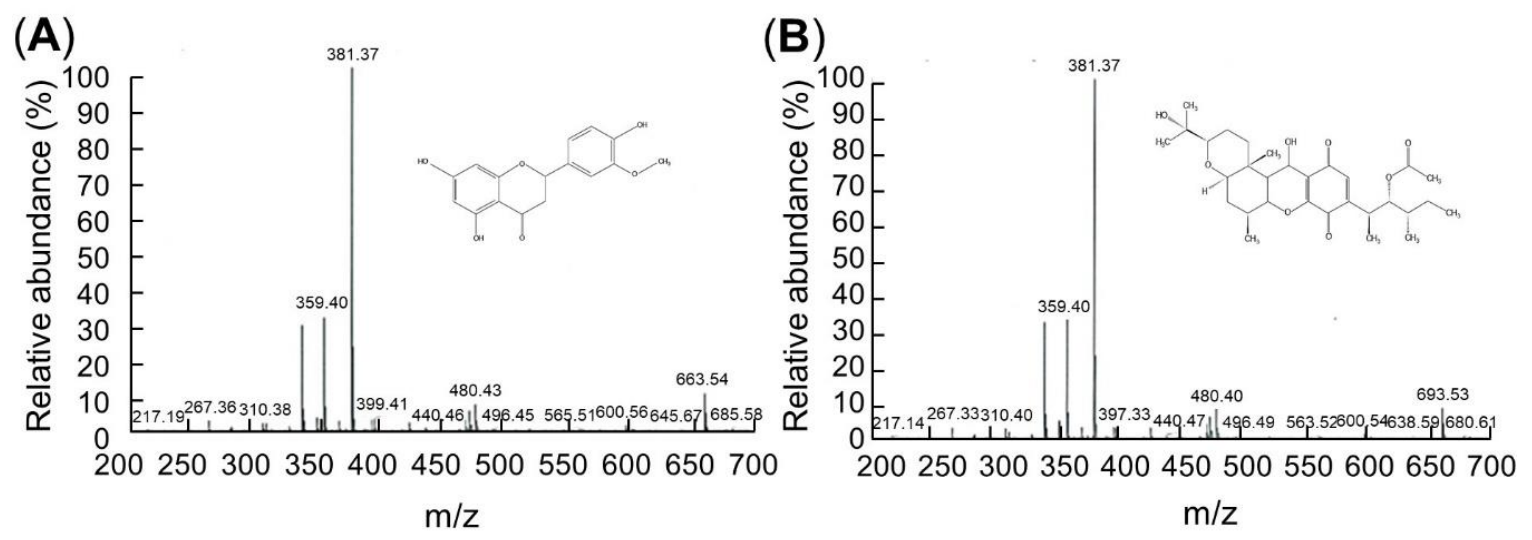

Figure 2. C7 and C9 LC/MS data. The flow rate was consistently $50 \mu \mathrm{L} / \mathrm{min}$ with a $320^{\circ} \mathrm{C}$ capillary temperature and $49 \mathrm{~V}$ of capillary voltage. (A) Chrysoeriol 7 (C7). Mass: 267.36 and $381.37 \mathrm{~m} / \mathrm{z}$, 5,7-dihydroxy-2-(4-hydroxy-3-methoxyphenyl)chromen-4-one, $\mathrm{C}_{16} \mathrm{H}_{12} \mathrm{O}_{6}$, molecular weight = 300.26 g/mol. (B) Cochlioquinone 9 (C9). Mass: 381.38 and $480.40 \mathrm{~m} / \mathrm{z}$, (3R)-9-[(1S,2R,3S)-2-acetyloxy1,3-dimethylpentyl]-1,2,3,4a $\beta, 5,6,6 \mathrm{a}, 12,12 \mathrm{a} \beta, 12 \mathrm{~b}$-decahydro-12 $\beta$-hydroxy-3 $\alpha$-(1-hydroxy-1-methylethyl) -6a $\alpha, 12 \mathrm{~b} \alpha$-dimethylpyrano[3,2-a]xanthene-8,11-dione, $\mathrm{C} 30 \mathrm{H} 44 \mathrm{O} 8$, molecular weight = 532.7 g/mol.

\subsection{Antimicrobial Activity Test of C7 and C9}

In the antimicrobial activity test of C7, the inhibition of growth of F. graminearum and P. graminicola were significantly different according to the concentration of the C7 treatment $(p<0.05)$ (Figure 3). At 1 week after inoculation, the inhibition rates of F. graminearum were $10.9 \%$ when treated with $100 \mathrm{ppm}, 26.6 \%$ when treated with $500 \mathrm{ppm}$ and 28.7\% when treated with $1000 \mathrm{ppm}$. It was confirmed that, as the treatment concentration of C7 increased, the growth of the fungi decreased; all media were overcultured at 2 weeks. The inhibition rates of P. graminicola were $22.6 \%, 48.54 \%$ and $62.27 \%$, showing high inhibitory effects at 1 week. However, at 2 weeks after inoculation, the inhibition rates were very low, $0.2 \%, 1.9 \%$ and $5.1 \%$ (Tables 2 and 3). In the antimicrobial activity test of C9, the inhibition of growth of C. herbarum, C. cladosporioides, G. zeae, F. graminearum and P. graminicola were significantly different according to the concentration of the C9 treatment $(p<0.05)$ (Figure 3). At 1 week after inoculation, the inhibition rates of $C$. herbarum were $5.0 \%, 9.9 \%$ and $10.1 \%$, respectively. At 2 weeks, the inhibition rates were $2.3 \%, 4.3 \%$ and $8.0 \%$, showing a weak inhibitory effect. The inhibition rates of C. cladosporioides were $12.4 \%, 14.3 \%$ and $15.5 \%$ at 1 week and $3.6 \%, 6.4 \%$ and $12.0 \%$ at 2 weeks, respectively. The inhibition rates of G. zeae were $7.6 \%, 8.1 \%$ and $24.6 \%$. With the 1000 ppm treatment, the inhibition rate increased significantly, and at 2 weeks it was overcultured. The inhibition rates of F. graminearum were $9.7 \%, 11.3 \%$ and $20.7 \%$ at 1 week, respectively, and overcultured in 2 weeks. The inhibition rates of $P$. graminicola were $26.4 \%, 27.3 \%$ and $36.2 \%$ at 1 week, respectively, showing a relatively high inhibitory effect. The inhibition rates at 2 weeks were $20.0 \%, 44.8 \%$ and $52.4 \%$, which were higher than those at Week 1 (Tables 4 and 5). 
The growth of $F$. graminearum and P. graminicola was inhibited by both C7 and C9. The antifungal activity against $F$. graminearum was slightly higher in $C 7$, and the antifungal activity against $P$. graminicola was higher in C9. Neither C7 nor C9 had an effect on the bacteria A. avenae subsp. avenae and X. campestris pv. campestris.

(A) Week

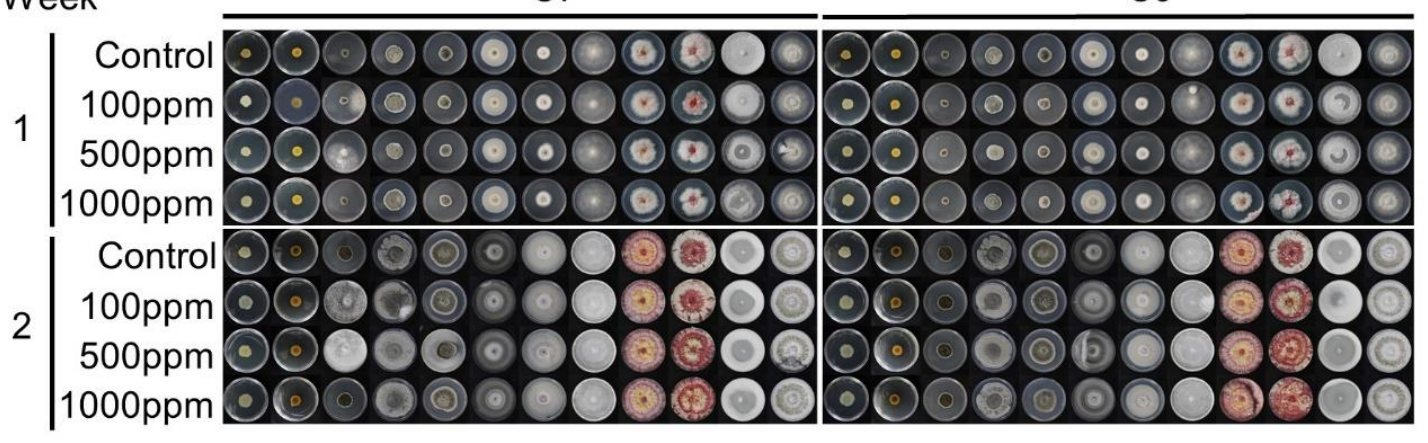

(B)
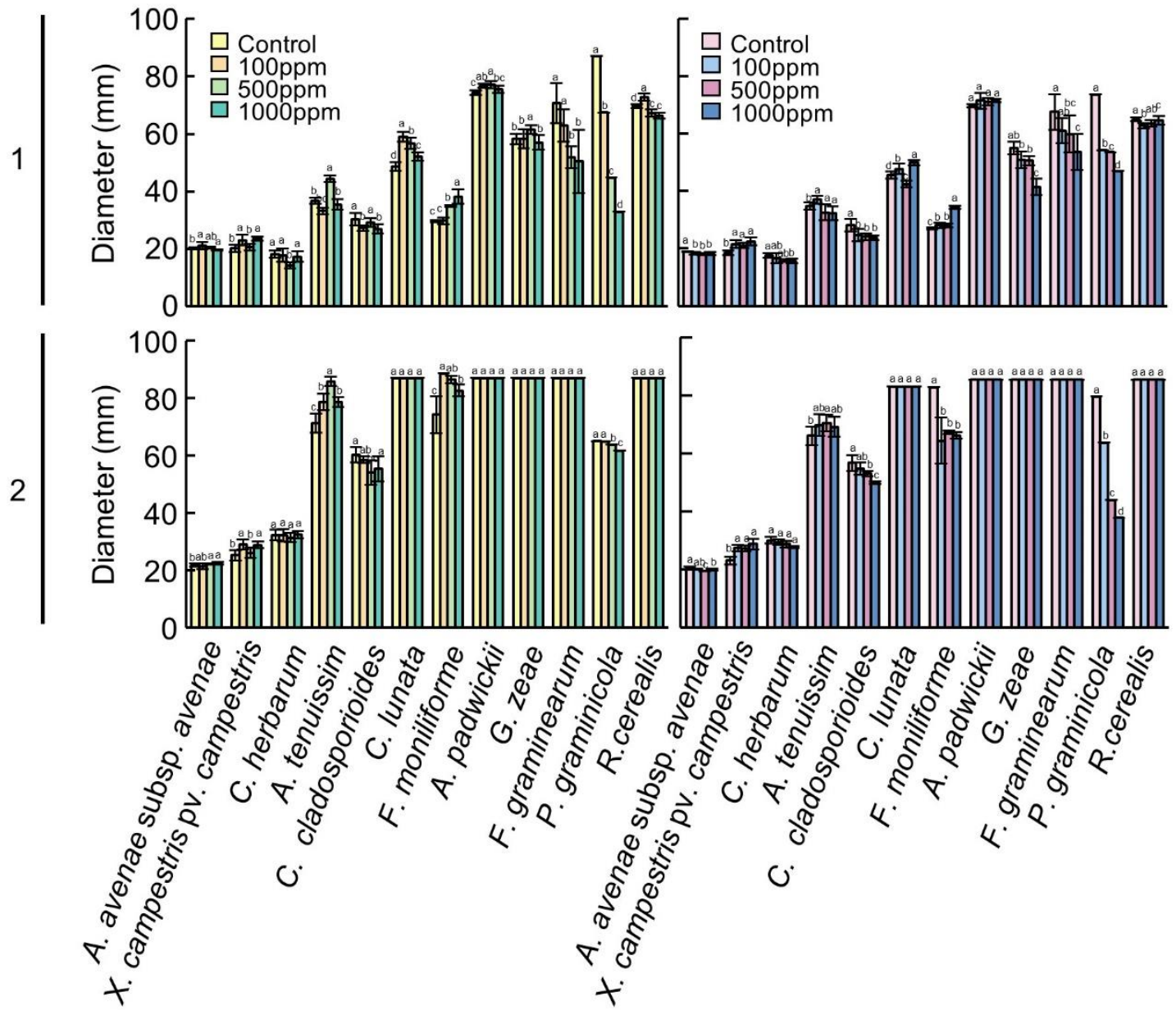

Figure 3. Antimicrobial activity of C7 (left panel) and C9 (right panel). (A)Visual growth of different bacterial and fungal strains. Bacteria were cultured in an LB medium and fungi were cultured in a PDA medium at $25^{\circ} \mathrm{C}$ in a dark state. The medium was treated with $\mathrm{C} 7$ and $\mathrm{C} 9$ at concentrations of $0 \mathrm{ppm}$, $100 \mathrm{ppm}, 500 \mathrm{ppm}$ and $1000 \mathrm{ppm}$, respectively. Colonies were observed after 1 and 2 weeks of growth after inoculation. (B) Colony diameter according to the concentration of the compounds at 1 week and 2 weeks after inoculation. Means with the same letters are not significantly different by Duncan's multiple range test at $p<0.05$. 
Table 2. Inhibition rate (\%) of chrysoeriol 7 against various pathogen species.

\begin{tabular}{|c|c|c|c|c|c|c|}
\hline \multirow{3}{*}{ Species } & \multicolumn{6}{|c|}{ Inhibition Rate (\%) } \\
\hline & \multicolumn{3}{|c|}{1 Week } & \multicolumn{3}{|c|}{2 Weeks } \\
\hline & 100 ppm & 500 ppm & 1000 ppm & 100 ppm & 500 ppm & 1000 ppm \\
\hline A. avenae subsp. avenae & -4.5 & -1.5 & 2.6 & 2.2 & -1.4 & -3.2 \\
\hline X. campestris pv. campestris & -13.5 & -1.4 & -16.3 & -15.0 & -3.5 & -14.5 \\
\hline C. herbarum & 2.2 & 21.9 & 4.7 & 0.2 & 2.8 & -0.6 \\
\hline A. tenuissima & 9.6 & -21.1 & 3.5 & -10.3 & -20.5 & -10.3 \\
\hline C. cladosporioides & 9.9 & 3.3 & 10.9 & 2.9 & 10.2 & 8.2 \\
\hline C. lunata & -21.1 & -16.6 & -7.1 & 0.0 & 0.0 & 0.0 \\
\hline F. moniliforme & -0.6 & -18.1 & -29.0 & -19.4 & -16.6 & -11.4 \\
\hline A. padwickii & -3.2 & -3.8 & -1.6 & 0.0 & 0.0 & 0.0 \\
\hline G. zeae & -0.2 & -5.7 & 2.1 & 0.0 & 0.0 & 0.0 \\
\hline F. graminearum & 10.9 & 26.6 & 28.7 & 0.0 & 0.0 & 0.0 \\
\hline P. graminicola & 22.6 & 48.5 & 62.3 & 0.2 & 1.9 & 5.1 \\
\hline R. cerealis & -4.4 & 3.4 & 4.8 & 0.0 & 0.0 & 0.0 \\
\hline
\end{tabular}

Table 3. Diameter of radial growth of various pathogen species against chrysoeriol 7.

\begin{tabular}{|c|c|c|c|c|c|c|c|c|c|c|}
\hline \multirow{3}{*}{ Species } & \multicolumn{10}{|c|}{ Diameter (mm) } \\
\hline & \multicolumn{5}{|c|}{1 Week } & \multicolumn{5}{|c|}{2 Weeks } \\
\hline & Control & $100 \mathrm{ppm}$ & $500 \mathrm{ppm}$ & $1000 \mathrm{ppm}$ & $p$ Value & Control & 100 ppm & $500 \mathrm{ppm}$ & $1000 \mathrm{ppm}$ & $p$ Value \\
\hline A. avenae subsp. avenae & $20.1 \pm 0.4 b^{z}$ & $21.1 \pm 1.3 a$ & $20.4 \pm 0.4 \mathrm{ab}$ & $19.6 \pm 0.3 b$ & $0.019 *$ & $21.7 \pm 0.5 b$ & $21.3 \pm 1.0 \mathrm{ab}$ & $22.0 \pm 0.3 a$ & $22.4 \pm 0.5 a$ & $0.025^{*}$ \\
\hline X. campestris pv. campestris & $20.3 \pm 1.3 b$ & $23.0 \pm 1.8 \mathrm{a}$ & $20.5 \pm 1.2 b$ & $23.5 \pm 0.8 \mathrm{a}$ & $<0.001 * *$ & $25.1 \pm 1.8 b$ & $28.9 \pm 1.6 \mathrm{a}$ & $26.0 \pm 1.9 b$ & $28.8 \pm 1.2 \mathrm{a}$ & $0.001 * *$ \\
\hline C. herbarum & $18.2 \pm 1.3 \mathrm{a}$ & $17.8 \pm 2.3 \mathrm{a}$ & $14.2 \pm 1.0 \mathrm{~b}$ & $17.3 \pm 1.7 \mathrm{a}$ & $0.002 * *$ & $32.1 \pm 1.8$ & $32.1 \pm 2.2$ & $31.3 \pm 1.6$ & $32.4 \pm 1.3$ & 0.722 \\
\hline A. tenuissima & $36.7 \pm 1.0 \mathrm{~b}$ & $33.2 \pm 1.1 \mathrm{bc}$ & $44.4 \pm 1.1 \mathrm{a}$ & $35.4 \pm 1.8 b$ & $<0.001 * *$ & $71.2 \pm 3.3 \mathrm{c}$ & $78.6 \pm 3.0 \mathrm{~b}$ & $85.8 \pm 1.5 \mathrm{a}$ & $78.6 \pm 1.8 \mathrm{~b}$ & $<0.001 * *$ \\
\hline C. cladosporioides & $30.2 \pm 2.2 \mathrm{a}$ & $27.2 \pm 1.0 \mathrm{~b}$ & $29.2 \pm 1.5 a$ & $26.9 \pm 1.6 b$ & $0.006^{* *}$ & $60.1 \pm 2.7 \mathrm{a}$ & $58.4 \pm 1.1 \mathrm{ab}$ & $54.0 \pm 4.3 \mathrm{bc}$ & $55.2 \pm 4.4 \mathrm{c}$ & $0.020 *$ \\
\hline C. lunata & $48.6 \pm 1.5 \mathrm{~d}$ & $58.9 \pm 1.7 \mathrm{a}$ & $56.7 \pm 2.0 \mathrm{~b}$ & $52.1 \pm 1.5 c$ & $<0.001 * *$ & $87.0 \pm 0.0$ & $87.0 \pm 0.0$ & $87.0 \pm 0.0$ & $87.0 \pm 0.0$ & 1.000 \\
\hline F. moniliforme & $29.5 \pm 0.3 c$ & $29.7 \pm 1.2 \mathrm{c}$ & $34.9 \pm 0.3 b$ & $38.1 \pm 2.5 \mathrm{a}$ & $<0.001^{* *}$ & $74.1 \pm 6.3 c$ & $88.5 \pm 0.0 \mathrm{a}$ & $86.4 \pm 1.2 \mathrm{ab}$ & $82.6 \pm 2.0 \mathrm{~b}$ & $<0.001 * *$ \\
\hline A. padwickii & $74.4 \pm 0.8 \mathrm{c}$ & $76.7 \pm 0.7 \mathrm{ab}$ & $77.1 \pm 1.3 \mathrm{a}$ & $75.6 \pm 1.3 b c$ & $0.001^{* *}$ & $87.0 \pm 0.0$ & $87.0 \pm 0.0$ & $87.0 \pm 0.0$ & $87.0 \pm 0.0$ & 1.000 \\
\hline G. zeae & $58.2 \pm 1.8 b$ & $58.3 \pm 3.4 \mathrm{~b}$ & $61.5 \pm 1.4 \mathrm{a}$ & $57.0 \pm 2.5 b$ & $0.024 *$ & $87.0 \pm 0.0$ & $87.0 \pm 0.0$ & $87.0 \pm 0.0$ & $87.0 \pm 0.0$ & 1.000 \\
\hline F. graminearum & $70.6 \pm 7.0 \mathrm{a}$ & $62.9 \pm 5.7 \mathrm{a}$ & $51.8 \pm 3.9 b$ & $50.4 \pm 11.1 \mathrm{~b}$ & $<0.001 * *$ & $87.0 \pm 0.0$ & $87.0 \pm 0.0$ & $87.0 \pm 0.0$ & $87.0 \pm 0.0$ & 1.000 \\
\hline P. graminicola & $87.0 \pm 0.8 \mathrm{a}$ & $67.4 \pm 0.2 b$ & $44.8 \pm 0.5 c$ & $32.8 \pm 0.4 \mathrm{~d}$ & $<0.001^{* *}$ & $64.9 \pm 0.7 a$ & $64.8 \pm 0.4 a$ & $63.7 \pm 0.4 b$ & $61.6 \pm 0.6 c$ & $<0.001^{* *}$ \\
\hline R. cerealis & $69.7 \pm 0.7 b$ & $72.7 \pm 1.2 \mathrm{a}$ & $67.3 \pm 1.2 \mathrm{c}$ & $66.3 \pm 1.1 c$ & $<0.001^{* *}$ & $87.0 \pm 0.0$ & $87.0 \pm 0.0$ & $87.0 \pm 0.0$ & $87.0 \pm 0.0$ & 1.000 \\
\hline
\end{tabular}

level. ** significant at the 0.01 level. 
Table 4. Inhibition rate (\%) of cochlioquinone 9 against various pathogen species.

\begin{tabular}{|c|c|c|c|c|c|c|}
\hline \multirow{3}{*}{ Species } & \multicolumn{6}{|c|}{ Inhibition Rate (\%) } \\
\hline & \multicolumn{3}{|c|}{1 Week } & \multicolumn{3}{|c|}{2 Weeks } \\
\hline & 100 ppm & 500 ppm & 1000 ppm & 100 ppm & 500 ppm & 1000 ppm \\
\hline A. avenae subsp. avenae & 3.6 & 4.8 & 3.9 & 1.7 & 4.5 & 2.1 \\
\hline X. campestris pv. campestris & -16.8 & -14.3 & -21.5 & -18.5 & -17.6 & -24.5 \\
\hline C. herbarum & 5.0 & 9.9 & 10.1 & 2.3 & 4.3 & 8.0 \\
\hline A. tenuissima & -6.4 & 6.3 & 7.1 & -5.6 & -6.7 & -4.7 \\
\hline C. cladosporioides & 12.4 & 14.3 & 15.5 & 3.6 & 6.4 & 12.0 \\
\hline C. lunata & -4.9 & 6.8 & -9.5 & 0.0 & 0.0 & 0.0 \\
\hline F. moniliforme & -3.9 & -3.6 & -27.1 & 22.2 & 18.7 & 20.0 \\
\hline A. padwickii & -2.5 & -1.9 & -2.6 & 0.0 & 0.0 & 0.0 \\
\hline G. zeae & 7.5 & 8.1 & 24.6 & 0.0 & 0.0 & 0.0 \\
\hline F. graminearum & 9.7 & 11.3 & 20.7 & 0.0 & 0.0 & 0.0 \\
\hline P. graminicola & 26.4 & 27.3 & 36.2 & 20.0 & 44.8 & 52.4 \\
\hline R. cerealis & 3.4 & 2.1 & 0.4 & 0.0 & 0.0 & 0.0 \\
\hline
\end{tabular}

Table 5. Diameter of radial growth of various pathogen species against chrysoeriol 9.

\begin{tabular}{|c|c|c|c|c|c|c|c|c|c|c|}
\hline \multirow{3}{*}{ Species } & \multicolumn{10}{|c|}{ Diameter (mm) } \\
\hline & \multicolumn{5}{|c|}{1 Week } & \multicolumn{5}{|c|}{2 Weeks } \\
\hline & Control & 100 ppm & $500 \mathrm{ppm}$ & $1000 \mathrm{ppm}$ & $p$ Value & Control & 100 ppm & $500 \mathrm{ppm}$ & $1000 \mathrm{ppm}$ & $p$ Value \\
\hline A. avenae subsp. avenae & $19.0 \pm 0.2 \mathrm{a}^{\mathrm{z}}$ & $18.3 \pm 0.4 b$ & $18.1 \pm 0.3 b$ & $18.3 \pm 0.6 b$ & $0.006^{* *}$ & $20.5 \pm 0.5 a$ & $20.2 \pm 0.3 \mathrm{ab}$ & $19.6 \pm 0.2 c$ & $20.1 \pm 0.3 b$ & $0.025^{*}$ \\
\hline X. campestris pv. campestris & $18.5 \pm 0.9 \mathrm{~b}$ & $21.6 \pm 1.3 a$ & $21.1 \pm 1.0 \mathrm{a}$ & $22.5 \pm 1.4 \mathrm{a}$ & $<0.001 * *$ & $23.2 \pm 1.3 b$ & $27.5 \pm 1.1 \mathrm{a}$ & $27.2 \pm 1.0 \mathrm{a}$ & $28.8 \pm 1.8 \mathrm{a}$ & $0.001 * *$ \\
\hline C. herbarum & $17.6 \pm 0.8$ & $16.7 \pm 1.7$ & $15.8 \pm 0.5$ & $15.8 \pm 0.8$ & 0.107 & $30.1 \pm 1.1 \mathrm{a}$ & $29.4 \pm 0.9 \mathrm{ab}$ & $28.8 \pm 1.2 \mathrm{bc}$ & $27.7 \pm 0.3$ & 0.722 \\
\hline A. tenuissima & $34.8 \pm 1.3 b$ & $37.0 \pm 1.4 \mathrm{a}$ & $32.6 \pm 2.7 \mathrm{a}$ & $32.3 \pm 2.5 \mathrm{a}$ & $<0.001 * *$ & $66.0 \pm 3.1 b$ & $69.7 \pm 3.7 \mathrm{ab}$ & $70.5 \pm 2.7 \mathrm{a}$ & $69.2 \pm 3.3 \mathrm{ab}$ & $<0.001 * *$ \\
\hline C. cladosporioides & $28.2 \pm 2.1 \mathrm{a}$ & $24.7 \pm 2.2 b$ & $24.1 \pm 1.2 b$ & $23.8 \pm 0.8 b$ & $0.001 * *$ & $56.8 \pm 2.7 \mathrm{a}$ & $54.7 \pm 2.1 \mathrm{ab}$ & $53.1 \pm 0.9 b$ & $49.9 \pm 0.4 c$ & $0.020 *$ \\
\hline C. lunata & $45.5 \pm 1.3 \mathrm{~d}$ & $47.8 \pm 1.8 \mathrm{~b}$ & $42.4 \pm 1.2 \mathrm{c}$ & $49.9 \pm 1.0 \mathrm{a}$ & $<0.001 * *$ & $83.0 \pm 0.0$ & $83.0 \pm 0.0$ & $83.0 \pm 0.0$ & $83.0 \pm 0.0$ & 1.000 \\
\hline F. moniliforme & $27.0 \pm 0.3 c$ & $28.1 \pm 0.9 b$ & $28.0 \pm 0.7 \mathrm{~b}$ & $34.3 \pm 0.6 \mathrm{a}$ & $<0.001^{* *}$ & $82.8 \pm 0.0 \mathrm{a}$ & $64.4 \pm 7.9 \mathrm{~b}$ & $67.3 \pm 0.6 b$ & $66.2 \pm 1.2 b$ & $<0.001 * *$ \\
\hline A. padwickii & $69.7 \pm 0.6$ & $71.4 \pm 2.8$ & $71.0 \pm 1.2$ & $71.5 \pm 0.5$ & 0.185 & $85.3 \pm 0.0$ & $85.3 \pm 0.0$ & $85.3 \pm 0.0$ & $85.3 \pm 0.0$ & 1.000 \\
\hline G. zeae & $55.0 \pm 2.2 \mathrm{ab}$ & $50.9 \pm 2.9 b$ & $50.6 \pm 1.6 \mathrm{~b}$ & $41.5 \pm 2.9 \mathrm{c}$ & $<0.001 * *$ & $85.3 \pm 0.0$ & $85.3 \pm 0.0$ & $85.3 \pm 0.0$ & $85.3 \pm 0.0$ & 1.000 \\
\hline F. graminearum & $67.5 \pm 6.2 \mathrm{a}$ & $61.0 \pm 4.4 \mathrm{ab}$ & $59.9 \pm 6.4 \mathrm{bc}$ & $53.5 \pm 6.3 c$ & $0.005^{* *}$ & $85.3 \pm 0.0$ & $85.3 \pm 0.0$ & $85.3 \pm 0.0$ & $85.3 \pm 0.0$ & 1.000 \\
\hline P. graminicola & $73.7 \pm 0.3 a$ & $54.2 \pm 0.6 \mathrm{~b}$ & $53.6 \pm 0.4 \mathrm{c}$ & $47.0 \pm 0.5 \mathrm{~d}$ & $<0.001^{* *}$ & $79.6 \pm 0.4 a$ & $63.7 \pm 0.6 b$ & $44.0 \pm 0.5 c$ & $37.9 \pm 0.5 \mathrm{~d}$ & $<0.001 * *$ \\
\hline R. cerealis & $64.9 \pm 0.7 \mathrm{a}$ & $62.7 \pm 0.9 b$ & $63.6 \pm 1.2 \mathrm{ab}$ & $64.6 \pm 1.5 \mathrm{a}$ & $0.010^{* *}$ & $85.3 \pm 0.0$ & $85.3 \pm 0.0$ & $85.3 \pm 0.0$ & $85.3 \pm 0.0$ & 1.000 \\
\hline
\end{tabular}

level. ** significant at the 0.01 level. 


\subsection{Phylogenetic Tree}

We obtained approximately $1500 \mathrm{bp} 16 \mathrm{~S}$ rRNA PCR amplification products from the 2 bacteria and 500-600 bp ITS region PCR amplification products from the 11 fungi (Figure 4a). The PCR amplified products were analyzed through the BLAST program of NCBI, and a neighbor-joining phylogenetic tree was created using the Mega X program. As expected, the bacteria and fungi were divided into two categories, phylogenetic and eukaryotic. G. zeae and F. graminearum grouped with the Fusarium genus with more than $99 \%$ identical nucleotide sequences. C. herbarum and C. cladosporioides showed a very high homology of $98.2 \%$ to the same Cladosporium genus, and the bootstrap value was very high at 99\%. G. zeae, F. graminearum, C. herbarum, and C. cladosporioides could be grouped together by the Ascomycota phylum, but showed low homology of $64-65.8 \%$ and a bootstrap value of $65 \%$. P. graminicola, which showed inhibitory effects by C7 and C9, did not belong to the Ascomycota phylum, and the homology was only 30.7-34.3\%, showing a distant relationship (Figure $4 b$ ).

(A)

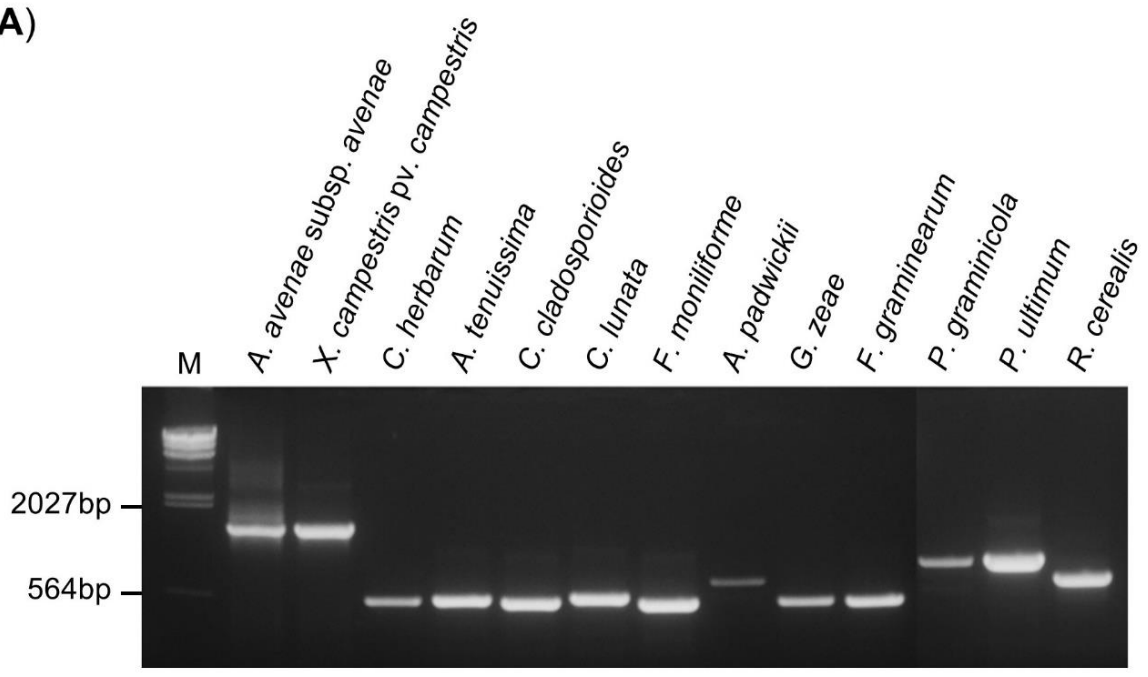

(B)
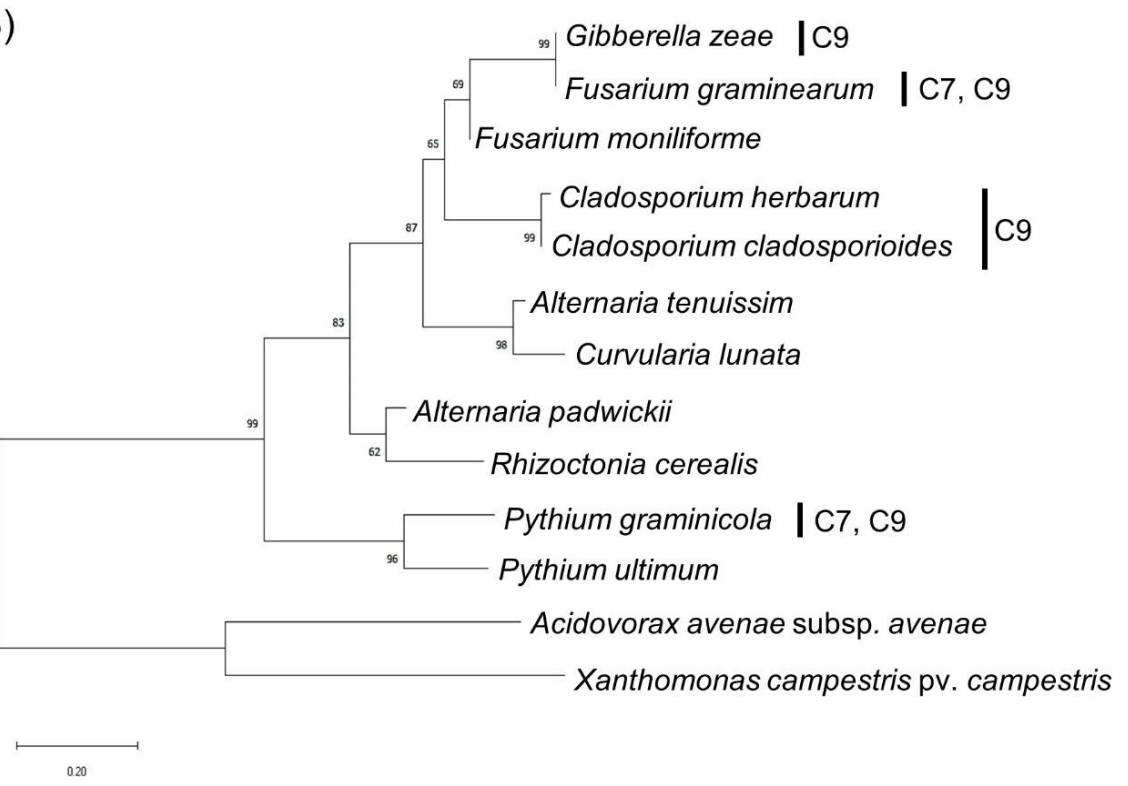

Figure 4. PCR amplification and phylogenetic tree. (A) Gel electrophoresis of the PCR products of the $16 \mathrm{~S}$ rRNA region and ITS region using a universal primer. The PCR product was run on a $0.8 \%$ agarose gel. M: $\lambda /$ Hind III DNA ladder. (B) Phylogenetic tree of the bacterial and fungal strains using the neighbor-joining method. The phylogenetic tree is based on the 16S rRNA and ITS gene sequences constructed with 1000 bootstraps in which the percentages over 50 are indicated in each node. 


\section{Discussion}

Chemical pesticides are widely used around the world to prevent pests and pathogens from attacking crops, and they have become a major cause of environmental pollution. Chemical pesticides are very efficient and appear to act quickly, but there are problems, such as residual toxicity and increased resistance by pests. Biological pesticides are alternatives to these organic synthetic pesticides. After the Rio summit agreement to replace $20 \%$ of the world's pesticides with biological pesticides, there is a clear movement to expand the availability of biological resources by developing new natural pesticides worldwide [33]. Among the currently discovered plant-derived biological pesticides, pyrethrin, which is eluted from pyrethrum flowers, has an insecticidal component and is mainly used to control moths and aphids [34]. Leaf extracts of Piper betle, Ocimum sanctum, Nyctanthes arbor-tristis and Citrus limon are known to inhibit the growth of pathogens of rice in vivo [35].

Chrysoeriol is an organic compound known as a 3'-O-methylated flavonoid and has a structure in which a methoxy group is attached to the $\mathrm{c} 3$ atom of the flavonoid backbone. It is abundantly present in many plants, fruits and medicinal herbs. Chrysoeriol is used in research on neuroprotection [36], anti-inflammatory, anticancer [37], antibacterial [38] and antioxidant [39] effects [40]. Cochlioquinone A is a major component of the bioactive pigments isolated from Bipolaris leersia and D. saccharhi. It is anti-angiogenic and has the inhibitory effects of diacylglycerol kinase and diacylglycerol acyltransferase. Cochlioquinone $B$ is a sesquiterpene metabolite, an inhibitor of NADH ubiquinone reductase, and a phytotoxic agent that inhibits root growth of finger millet and rice at a $100 \mathrm{ppm}$ concentration [26]. Cochlioquinone $\mathrm{D}$ is a physiologically active natural product that inhibits root growth of Lolium multiflorum [41]. Cochlioquinone 9 is distinguished from cochlioquinone A in that C26 (methyl group) is not bound to C14 but is bound to C15.

In separating chrysoeriol and cochlioquinone from rice inoculated with WBPHs, it is possible to extract a large amount of material faster than when not inoculated, increasing the efficiency and reducing the cost [42]. The highest amount of C7 and C9 was extracted from TN1, a susceptible cultivar, at the seedling stage. However, the amount of material can be different depending on various factors such as the growth time, the period of inoculation and the extraction method. According to Park et al. (2014), there is a large difference in damage between resistant rice cultivars and susceptible cultivars after 25 days of inoculation [31]. In this experiment, compounds were extracted under a single condition, so further experimentation is required to determine under which conditions the $\mathrm{C} 7$ and $\mathrm{C} 9$ content of the resistant cultivars will be higher compared to other varieties. In the LC/MS analysis of the separated material in the present study, C7 showed molecular weights of 267.36 and $381.37 \mathrm{~m} / \mathrm{z}$, and C9 showed molecular weights of 381.38 and $480.40 \mathrm{~m} / \mathrm{z}$. This is consistent with the molecular weights of $\mathrm{C7}$ and $\mathrm{C} 9$, as previously known [31]; the authors reported that the molecular weight of Chrysoeriol 7 was 267.33, 341.50, 353.42 and $381.50 \mathrm{~m} / \mathrm{z}$, and that of Cochlioquinone 9 was 381.50 and $469.42 \mathrm{~m} / \mathrm{z}$. Since the molecular weight of the material separated in this experiment almost matched, it was judged to be the same material.

Looking at the results of the inhibition rate against the pathogens when $C 7$ and $C 9$ were treated with varying concentrations, when $C 7$ was treated, the inhibition rate against $F$. graminearum at 1 week was $10.9,26.6$ and $28.7 \%$, respectively, and the inhibition rate significantly increased when treated with $500 \mathrm{ppm}$. However, when processing $1000 \mathrm{ppm}$, it increases very little. The inhibition rate against P. graminicola was $22.6 \%, 48.54 \%$ and $62.27 \%$, showing high inhibitory effects, and the inhibition rate was also greatly increased in proportion to the concentration of the compound. However, at 2 weeks after inoculation, the inhibition rate was very low (Table 2). When looking at the inhibition rate when C9 was treated, when 500 ppm was used in C. herbarum and C. cladosporioides at 1 week, the inhibition rate was $9.9 \%$ and $14.3 \%$, which was the most efficient compared to the other concentration. At 2 weeks, both showed weak inhibitory effects overall. In G. zeae, the inhibition rate was $24.6 \%$ when treated with 1000 ppm at 1 week, which was higher than when 500 ppm was used. After 1 week, the inhibition rate of $F$. graminearum and P. graminicola increased significantly to $20.7 \%$ and $36.2 \%$, respectively, when $1000 \mathrm{ppm}$ was used, and the inhibition rate of $P$. graminicola further increased after 2 weeks 
(Table 3). C7 has an inhibitory effect against two pathogens, F. graminearum and P. graminicola, and C9 has an inhibitory effect against a wider range of fungi, including F. graminearum and P. graminicola, but the inhibitory effect was higher in C7. The most efficient control concentration was different, depending on the type of pathogen when the compounds were treated, but the most efficient treatment concentration for simultaneous control of several fungal pathogens was $500 \mathrm{ppm}$.

The bacterial 16S rRNA and the fungal ITS region were used to investigate the genetic similarity between microbes whose growth was inhibited by C7 and C9 through the phylogenetic tree. Most of the 16S rRNA sequences are quite conserved, although high sequence diversity appears in some sections. While there is little diversity between homogeneous species, diversity appears between other species, so it is used to identify prokaryotes [43]. The length of the ITS region of the fungus is not long, so it can be easily analyzed. It has been widely used for systematic analysis because it can be used even among nearby taxa due to its rapid mutation rate [44]. As a result of systematic analysis, microorganisms were largely divided into three groups. G. zeae and F. graminearum cause scab in rice and produce fungal toxins that affect rice safety and are toxic to the immune system and digestive system [45]. The outbreak of mycotoxins caused by contamination of $F$. graminearum has been reported steadily around the world, and it is estimated that $25 \%$ of the world's grain production, including rice, is contaminated with mycotoxins [46]. In Korea, scab disease caused by F. graminearum occurred widely in the southern regions during the harvesting season in 1963, resulting in a reduction of yield of 40-60\% in some regions and $80-100 \%$ in severe regions [47]. C. herbarum and C. cladosporioides are species in the genus Cladosporium, which causes spotting symptoms on crops, causes allergies to livestock and promotes asthma. In addition, each pathogen causes false blast and ear blight, which directly damages the ear of rice, not only reducing the quantity but also the quality of the harvest [48]. P. graminicola is a plant pathogen that infects grains such as barley, wheat, rice and beans. In rice, it causes blight [49]. Damping-off caused by P. graminicola is a disease that affects the early growth of the seedling, infringing on the branch of the hypocotyl and causing the seedling to fall. In the end, it falls and dies. When a lot of damping-off occurs, the seedlings are insufficient, which causes great damage to the planting [50]. However, we found no antimicrobial effect of $C 7$ and $C 9$ on P. ultimum, which has $83.7 \%$ homology with P. graminicola, so this needs to be confirmed.

Research using microorganisms, plant extracts and natural enemies is being carried out to develop biological pesticides to replace chemical pesticides and develop eco-friendly agriculture. However, the production of plant extracts is small; thus, the amount that can be used for pesticides in areas with high demands is extremely limited. The extracts can be effective and could be used as biological pesticides and antibacterial agents if a mass extraction method and an automatic analysis system for substances are established in the future.

\section{Conclusions}

In this study, in order to overcome the environmental damage caused by chemical pesticides, we tried to find eco-friendly biopesticide material that can control pests and pathogens. Chrysoeriol 7 and cochlioquinone 9, which are insect-resistant compounds, were extracted from rice and their antimicrobial activity against major pathogens causing disease in rice was examined. The results showed that chrysoeriol 7 had antifungal activity against Fusarium graminearum and Pythium graminicola and cochlioquinone 9 had antifungal activity against Cladosporium herbarum, Cladosporium cladosporioides, Gibberella zeae, Fusarium graminearum and Pythium graminicola. These results indicate that they are effective in limiting the growth of some pathogens and show their potential as alternatives to harmful chemical pesticides. These findings can also contribute to the basic research of eco-friendly materials to use as pesticides in rice farming.

Author Contributions: Conceptualization, Y.-H.J.; investigation; Y.-H.J.; writing—original draft, Y.-H.J.; writing—review and editing, Y.-H.J.; J.-R.P., K.-M.K.; supervised the project, K.-M.K. All authors have read and agreed to the published version of the manuscript.

Funding: This research received no external funding. 
Acknowledgments: This work was supported by a grant from the new breeding technologies development program (Project No. PJ014793012020), Rural Development Administration, Republic of Korea.

Conflicts of Interest: The authors declare no conflict of interest.

\section{References}

1. Matthews, R.B.; Kropff, M.J.; Horie, T.; Bachelet, D. Simulating the impact of climate change on rice production in Asia and evaluating options for adaptation. Agric. Syst. 1997, 54, 399-425. [CrossRef]

2. Ray, D.K.; Mueller, N.D.; West, P.C.; Foley, J.A. Yield trends are insufficient to double global crop production by 2050. PLoS ONE 2013, 8, e66428. [CrossRef]

3. Seo, B.Y.; Kwon, Y.H.; Jung, J.K.; Kim, G.H. Electrical penetration graphic waveforms in relation to the actual positions of the stylet tips of Nilaparvata lugens in rice tissue. J. Asia Pac. Entomol. 2009, 12, 89-95. [CrossRef]

4. Lee, Y.; Ra, D.; Yeh, W.; Choi, H.; Myung, I.; Lee, S.; Lee, Y.; Han, S.; Shim, H. Survey of major disease incidence of rice in Korea during 1999-2008. Res. Plant. Dis. 2010, 16, 183-190. [CrossRef]

5. Liu, W.; Liu, J.; Triplett, L.; Leach, J.E.; Wang, G.L. Novel insights into rice innate immunity against bacterial and fungal pathogens. Annu. Rev. Phytopathol. 2014, 52, 213-241. [CrossRef]

6. Matsumura, M. Characteristics of recent population growth patterns of the whitebacked planthopper, Sogatella furcifera Horvath in the Hokuriku district (in Japanese). Proc. Assoc. Plant. Prot. Hokuriku 1991, 39, 47-50.

7. Turner, R.; Song, Y.-H.; Uhm, K.-B. Numerical model simulations of brown planthopper Nilaparvata lugens and white-backed planthopper Sogatella furcifera (Homoptera: Delphacidae) migration. Bull. Entomol. Res. 1999, 89, 557-568. [CrossRef]

8. Ha, H.Y.; Ra, D.S.; Shin, W.C.; Im, G.J.; Park, J.E. Survey of pesticide use in fruit vegetables, fruits, and rice cultivation areas in Korea. J. Korean Phys. Ther. 2012, 16, 395-400. [CrossRef]

9. Backman, P.A.; Sikora, R.A. Endophytes: An emerging tool for biological control. Biol. Control 2008, 46, 1-3. [CrossRef]

10. Huang, S.; Zhang, Z.; Li, Y.; Li, Y.; Xu, H. Anti-insect activity of the methanol extracts of fern and gymnosperm. Agric. Sci. China 2010, 9, 249-256. [CrossRef]

11. Gupta, S.; Dikshit, A.K. Biopesticides: An ecofriendly approach for pest control. J. Biopestic. 2010, 3, 186.

12. Arnason, J.T.; Philogène, B.J.R.; Morand, P.; Imrie, K.; Iyengar, S.; Duval, F.; Soucy-Breau, C.; Scaiano, J.C.; Werstiuk, N.H.; Hasspieler, B.; et al. Naturally occurring and synthetic thiophenes as photoactivated insecticides. ACS Symp. Ser. 1989, 387, 164-172. [CrossRef]

13. Schröder, G.; Wehinger, E.; Lukačin, R.; Wellmann, F.; Seefelder, W.; Schwab, W.; Schröder, J. Flavonoid methylation: A novel 4'-O-methyltransferase from Catharanthus roseus, and evidence that partially methylated flavanones are substrates of four different flavonoid dioxygenases. Phytochemistry 2004, 65, 1085-1094. [CrossRef]

14. Kim, K.M.; Park, Y.H. Studies of the life cycle and rearing methods of Whitebacked planthopper (Sogatella furcifera Horvath). J. Life Sci. 2018, 28, 357-360. [CrossRef]

15. Teubert, H.; Wünsche, G.; Herrmann, K. Flavonols and flavones of vegetables. VIII. Flavones of carrot leaves (author's transl). Z. Lebensm-Unters. Und-Forsch. 1977, 165, 147-150. [CrossRef] [PubMed]

16. Harborne, J.B.; Williams, C.A. Flavonoid patterns in the fruits of the Umbelliferae. Phytochemistry 1972, 11, 1741-1750. [CrossRef]

17. Lin, Y.; Shi, R.; Wang, X.; Shen, H.M. Luteolin, a flavonoid with potential for cancer prevention and therapy. Curr. Cancer Drug Targets 2008, 8, 634-646. [CrossRef]

18. José Angelo, S.Z.; Pierre, H.C.; Jean-Charles, Q.; Henri-Philippe, H.; Adam, K.; Pascal, R. Production of Sinorhizobium meliloti nod gene activator and repressor flavonoids from Medicago sativa roots. Mol. Plant. Microbe Interact. 1998, 11, 784-794. [CrossRef]

19. Ferreira, J.F.; Luthria, D.L.; Sasaki, T.; Heyerick, A. Flavonoids from Artemisia annua L. as antioxidants and their potential synergism with artemisinin against malaria and cancer. Molecules 2010, 15, 3135-3170. [CrossRef]

20. Tagousop, C.N.; Ekom, S.E.; Ngnokam, D.; Voutquenne-Nazabadioko, L. Antimicrobial activities of flavonoid glycosides from Graptophyllum grandulosum and their mechanism of antibacterial action. BMC Complement. Altern. Med. 2018, 18,1-10. [CrossRef] 
21. Han, L.; Gao, X.; Xia, T.; Zhang, X.; Li, X.; Gao, W. Effect of digestion on the phenolic content and antioxidant activity of celery leaf and the antioxidant mechanism via Nrf2/HO-1 signaling pathways against Dexamethasone. J. Food Biochem. 2019, 43, e12875. [CrossRef]

22. Choi, D.Y.; Lee, J.Y.; Kim, M.R.; Woo, E.R.; Kim, Y.G.; Kang, K.W. Chrysoeriol potently inhibits the induction of nitric oxide synthase by blocking AP-1 activation. J. Biomed. Sci. 2005, 12, 949-959. [CrossRef] [PubMed]

23. Boucias, D.G.; Zhou, Y.; Huang, S.; Keyhani, N.O. Microbiota in insect fungal pathology. Appl. Microbiol. Biotechnol. 2018, 102, 5873-5888. [CrossRef]

24. Boucias, D.G.; Lietze, V.U.; Teal, P. Chemical signals that mediate insect-fungal interactions. In Biocommunication of Fungi; Springer: Dordrecht, The Netherlands, 2012; pp. 305-306. [CrossRef]

25. Bicalho, B.; Gonçalves, R.A.; Zibordi, A.P.; Manfio, G.P.; Marsaioli, A.J. Antimicrobial compounds of fungi vectored by Clusia spp. (Clusiaceae) pollinating bees. Z. Naturforsch. C J. Biosci. 2003, 58, 746-751. [CrossRef] [PubMed]

26. Canonica, L.; Beretta, M.G.; Colombo, L.; Gennari, C.; Ranzi, B.M.; Scolastico, C. Biosynthesis of cochlioquinones. J. Chem. Soc. Perkin Trans. 1 1980, 2686-2690. [CrossRef]

27. Yoganathan, K.; Yang, L.K.; Rossant, C.; Huang, Y.; Ng, S.; Butler, M.S.; Buss, A.D. Cochlioquinones and epi-cochlioquinones. J. Antibiot. 2004, 57, 59-63. [CrossRef] [PubMed]

28. Schaeffer, J.M.; Frazier, E.G.; Bergstrom, A.R.; Williamson, J.M.; Liesch, J.M.; Goetz, M.A. Cochlioquinone A, a nematocidal agent which competes for specific $[3 \mathrm{H}]$ ivermectin binding sites. J. Antibiot. 1990, 43, 1179-1182. [CrossRef]

29. Jung, H.J.; Lee, H.B.; Lim, C.H.; Kim, C.J.; Kwon, H.J. Cochlioquinone A1, a new anti-angiogenic agent from Bipolaris zeicola. Bioorg. Med. Chem. 2003, 11, 4743-4747. [CrossRef]

30. Kim, T.H.; Kim, K.M.; Manigbas, N.L.; Yi, G.H.; Sohn, J.K. Identification of quantitative trait loci for resistance to whitebacked planthopper (Sogatella furcifera) in rice with Milyang 46 (“Cheongcheong”) background. Philipp. J. Crop. Sci. 2013, 38, 30-36. [CrossRef]

31. Park, S.G.; Kiswara, G.; Lee, G.H.; Yang, W.H.; Chang, A.; Kim, K.M. Analysis of QTL associated with WBPH and identification of WBPH mediated compounds in rice (Oryza sativa L.). Korean Breed. Sci. 2014, 132.

32. Kim, S.W.; Jung, J.H.; Lamsal, K.; Kim, Y.S.; Min, J.S.; Lee, Y.S. Antifungal effects of silver nanoparticles (AgNPs) against various plant pathogenic fungi. Mycobiology 2012, 40, 53-58. [CrossRef]

33. Lee, H.K.; Lee, J.J.; Moon, J.M.; Bock, P.S. Fumigant activities of Arctium lappa extracts against Callosobruchus chinensis adult. J. Agric. Life Sci. 2014, 45, 23-27. [CrossRef]

34. Walia, S.; Saha, S.; Tripathi, V.; Sharma, K.K. Phytochemical biopesticides: Some recent developments. Phytochem. Rev. 2017, 16, 989-1007. [CrossRef]

35. Tewari, S.N.; Nayak, M. Activity of four plant leaf extracts against three fungal pathogens of rice. Trop. Agric. 1991, 68, 373-375.

36. Nabavi, S.F.; Braidy, N.; Gortzi, O.; Sobarzo-Sanchez, E.; Daglia, M.; Skalicka-Woźniak, K.; Nabavi, S.M. Luteolin as an anti-inflammatory and neuroprotective agent: A brief review. Brain Res. Bull. 2015, 119, 1-11. [CrossRef]

37. Luo, Y.; Shang, P.; Li, D. Luteolin: A flavonoid that has multiple cardio-protective effects and its molecular mechanisms. Front. Pharmacol. 2017, 8, 692. [CrossRef]

38. Miski, M.; Ulubelen, A.; Johansson, C.; Mabry, T.J. Antibacterial activity studies of flavonoids from Salvia palaestina. J. Nat. Prod. 1983, 46, 874-875. [CrossRef]

39. Mishra, B.; Priyadarsini, K.I.; Kumar, M.S.; Unnikrishnan, M.K.; Mohan, H. Effect of O-glycosilation on the antioxidant activity and free radical reactions of a plant flavonoid, chrysoeriol. Bioorg. Med. Chem. 2003, 11, 2677-2685. [CrossRef]

40. Bashyal, P.; Parajuli, P.; Pandey, R.P.; Sohng, J.K. Microbial biosynthesis of antibacterial chrysoeriol in recombinant Escherichia coli and bioactivity assessment. Catalysts 2019, 9, 112. [CrossRef]

41. Arayama, M.; Nehira, T.; Maeda, H.; Tanaka, K.; Miyagawa, H.; Ueno, T.; Hosokawa, S.; Hashimoto, M. Isolation, ECD assisted structural analyses, biosynthetic discussions, and biological activities of epi-cochlioquinones D and its derivatives. Tetrahedron 2015, 71, 4788-4794. [CrossRef]

42. Kim, K.M.; Yun, B.W. Method for Isolating Flavonoids from Rice Plant Inoculated with Whitebacked Planthopper. U.S. Patent No. 10,562,911, 18 February 2020.

43. Lane, D.J.; Pace, B.; Olsen, G.J.; Stahl, D.A.; Sogin, M.L.; Pace, N.R. Rapid determination of $16 S$ ribosomal RNA sequences for phylogenetic analyses. Proc. Natl. Acad. Sci. USA 1985, 82, 6955-6959. [CrossRef] [PubMed] 
44. Suga, H.; Hasegawa, T.; Mitsui, H.; Kageyama, K.; Hyakumachi, M. Phylogenetic analysis of the phytopathogenic fungus Fusarium solani based on the rDNA-ITS region. Mycol. Res. 2000, 104, 1175-1183. [CrossRef]

45. Goswami, R.S.; Kistler, H.C. Heading for disaster: Fusarium graminearum on cereal crops. Mol. Plant. Pathol. 2004, 5, 515-525. [CrossRef]

46. Chung, H.S. Cereal scab causing mycotoxicoses in Korea and present status of mycotoxin researches. Korean J. Mycol. 1975, 3, 31-36.

47. Tanaka, T.; Hasegawa, A.; Yamamoto, S.; Lee, U.-S.; Sugiura, Y.; Ueno, Y. Worldwide contamination of cereals by the fusarium mycotoxins nivalenol, deoxynivalenol, and zearalenone. 1. Survey of 19 Countries. J. Agric. Food Chem. 1988, 36, 979-983. [CrossRef]

48. Chaibub, A.A.; Sousa, T.P.; Araújo, L.G.; Filippi, M.C.C. Molecular and morphological characterization of rice phylloplane fungi and determination of the antagonistic activity against rice pathogens. Microbiol. Res. 2020, 231, 126353. [CrossRef]

49. Kobori, H.; Tojo, M.; Hasunuma, N.; Ohki, S.T. Materials of Pythium flora in Japan (XI): Characterization of Pythium graminicola causing seedling blight in rice. Sci. Rep. Grad. Sch. Agric. Biol. Sci. Osaka Pref. Univ. 2004, 56, 1-5. [CrossRef]

50. Ling, Y.; Xia, J.; Koji, K.; Zhang, X.; Li, Z. First report of damping-off caused by Pythium arrhenomanes on rice in China. Plant Dis. 2018, 102, 2382. [CrossRef]

Publisher's Note: MDPI stays neutral with regard to jurisdictional claims in published maps and institutional affiliations.

(C) 2020 by the authors. Licensee MDPI, Basel, Switzerland. This article is an open access article distributed under the terms and conditions of the Creative Commons Attribution (CC BY) license (http://creativecommons.org/licenses/by/4.0/). 